\title{
Karolina Malesa
}

e-mail: karolinamalesa1@gmail.com

\section{Mieszkalnictwo w Polsce w latach 2010-2018}

\author{
https://doi.org/10.25312/2391-5129.30/2020_07km
}

Artykuł porusza tematykę stanu mieszkalnictwa w Polsce w latach 2010-2018. Celem artykułu jest omówienie warunków mieszkaniowych w Polsce. Temat opisano głównie na podstawie analizy danych GUS dotyczących rynku lokali mieszkalnych w latach 2010-2018. Struktura artykułu jest następująca: po krótkim wprowadzeniu, w pierwszej części tekstu, w sposób syntetyczny, przedstawiono wielkość zasobów mieszkaniowych w Polsce. W drugiej części artykułu przeanalizowano podstawowe warunki mieszkaniowe na wojewódzkich rynkach lokali mieszkalnych w Polsce (przeciętna powierzchnia użytkowa mieszkania, przeciętna powierzchnia mieszkania przypadająca na 1 osobę, przeciętna liczba izb w mieszkaniu, przeciętna liczba osób przypadająca na 1 mieszkanie i na 1 izbę). W części trzeciej omówiono obrót na rynku lokali mieszkalnych. Czwarta część poświęcona jest roli kredytu hipotecznego w finansowaniu zakupu nieruchomości. Syntetyczna konstatacja wieńczy niniejszy tekst.

Słowa kluczowe: nieruchomość, mieszkanie, rynek nieruchomości, nieruchomości mieszkalne, ceny nieruchomości, popyt na rynku nieruchomości, podaż na rynku nieruchomości, rynek pierwotny, rynek wtórny, lokale mieszkalne, warunki mieszkaniowe

\section{Wprowadzenie}

Celem niniejszego artykułu jest omówienie stanu mieszkalnictwa w Polsce na przestrzeni ostatnich 10 lat. Analiza została podjęta na podstawie danych Głównego Urzędu Statystycznego dotyczących rynku lokali mieszkalnych w latach 2010-2018.

* Mgr Karolina Malesa - doktorantka w Katedrze Zarządzania i Finansów Szkoły Głównej Handlowej w Warszawie. 
Artykuł składa się z czterech części. W pierwszej części opracowania omówiono, jak kształtuje się wielkość zasobów mieszkaniowych w Polsce. Z kolei w drugiej części tekstu przedstawiono warunki mieszkaniowe, w tym na wojewódzkich rynkach lokali mieszkalnych. Analizie zostały poddane takie wskaźniki, jak przeciętna powierzchnia użytkowa mieszkania, przeciętna powierzchnia mieszkania przypadająca na 1 osobę, przeciętna liczba izb w mieszkaniu, przeciętna liczba osób przypadająca na 1 mieszkanie i na 1 izbę. Ponadto zostało omówione wyposażenie mieszkań w instalacje sanitarno-techniczne. Z kolei w części trzeciej omówiono obrót na rynku lokali mieszkalnych w Polsce, uwzględniając sytuację w poszczególnych województwach kraju. W części czwartej zostały przedstawione podstawowe dane mówiące o wielkości rynku kredytów mieszkaniowych w Polsce. Syntetyczna konstatacja wieńczy niniejsze opracowanie.

\section{Zasoby mieszkaniowe w Polsce w latach 2010-2018}

Zasoby mieszkaniowe w Polsce powiększają się nieustannie od okresu transformacji. Od 2000 roku w Polsce obserwujemy poprawę sytuacji mieszkaniowej dzięki budowie nowych mieszkań, remontom już istniejących zasobów mieszkaniowych oraz zmianie charakteru przeznaczenia powierzchni niemieszkalnych. Ponadto sytuacja demograficzna ogranicza zapotrzebowanie na nowe mieszkania. Według danych Głównego Urzędu Statystycznego liczba mieszkań w zasobie krajowym wzrosła z 13,5 mln w 2010 roku do 14,6 mln w 2018 roku. Na koniec 2018 roku na terenach miejskich znajdowało się 9,9 mln mieszkań o łącznej powierzchni $637,8 \mathrm{mln} \mathrm{m}$, na terenach wiejskich natomiast zlokalizowanych było 4,8 mln mieszkań o łącznej powierzchni $446,3 \mathrm{mln} \mathrm{m}^{2}$. W analizowanym okresie liczba mieszkań przypadająca na 1000 osób wzrosła z 350 mieszkań w 2010 roku do 380 mieszkań w 2018 roku.

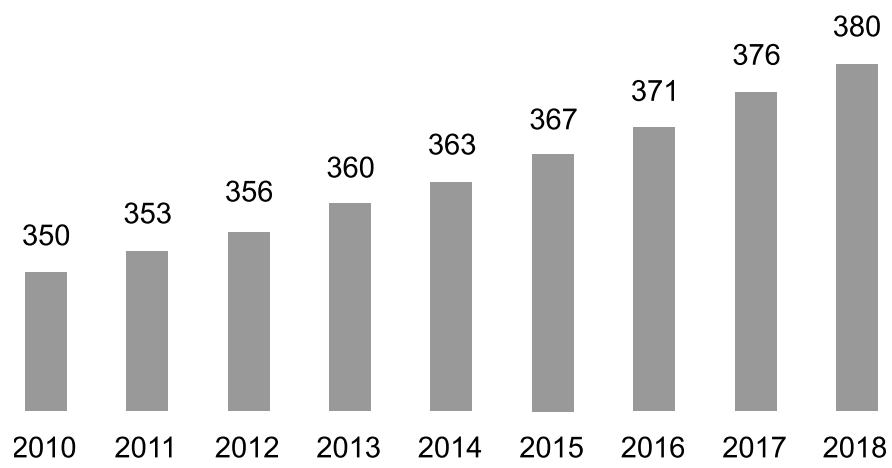

Rysunek 1. Zasoby mieszkaniowe w Polsce w latach 2010-2018 (w tys.)

Źródło: opracowanie własne na podstawie Rocznik Statystyczny Rzeczypospolitej Polskiej 2019, Rocznik Statystyczny Rzeczypospolitej Polskiej 2014. 


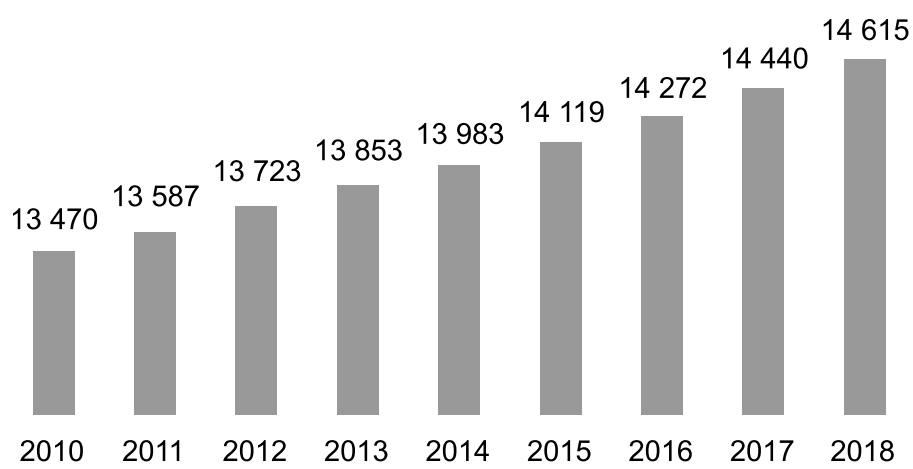

Rysunek 2. Zasoby mieszkaniowe na 1000 osób w Polsce w latach 2010-2018

Źródło: opracowanie własne na podstawie Rocznik Statystyczny Rzeczypospolitej Polskiej 2019, Rocznik Statystyczny Rzeczypospolitej Polskiej 2014.

Analizując dane dotyczące zasobów mieszkaniowych w poszczególnych województwach, widzimy znaczne dysproporcje. W 2018 roku spośród wszystkich zasobów mieszkaniowych zlokalizowanych na terenach miejskich aż $23,5 \%$ z nich skupionych było w pięciu największych miastach Polski, tj. Warszawie, Krakowie, Łodzi, Wrocławiu i Poznaniu. Poniższy wykres pokazuje wielkość zasobów mieszkaniowych przypadającą na 1000 osób w poszczególnych województwach Polski na przestrzeni 10 lat. Można zaobserwować, że w całym analizowanym okresie wskaźnik dla województwa podkarpackiego był znacznie niższy od pozostałych województw i w 2018 roku wynosił 315 mieszkań na 1000 osób.

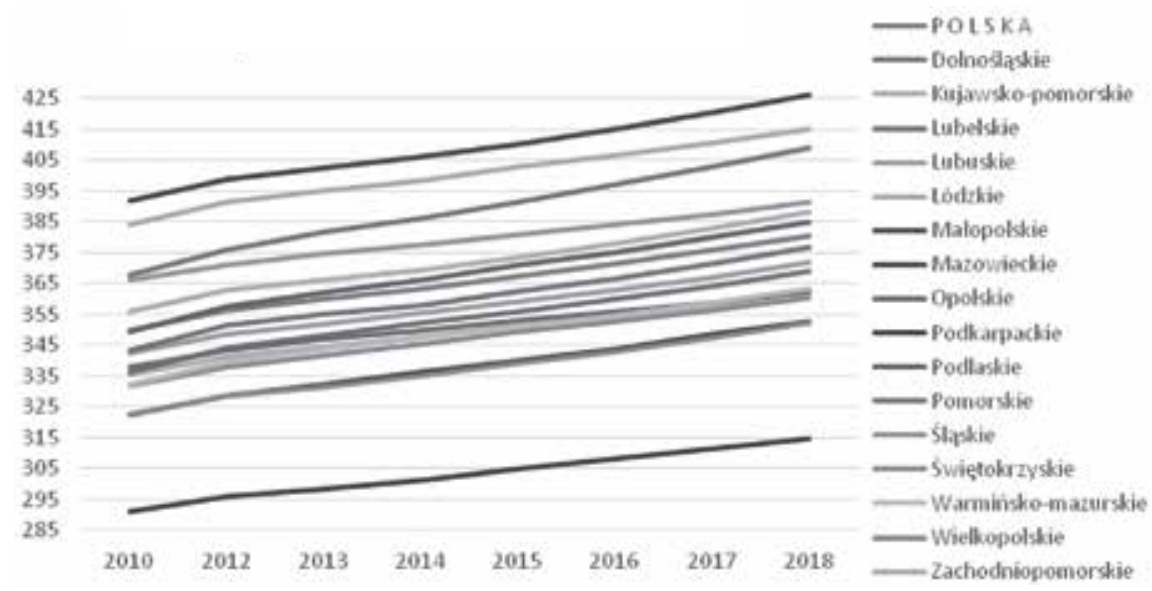

Rysunek 3. Zasoby mieszkaniowe na 1000 osób w Polsce według województw w latach 2010-2018

Źródło: opracowanie własne na podstawie Rocznik Statystyczny Województw z lat 2011-2019. 
Wskaźnik wyższy niż krajowy w 2018 roku odnotowało województwo mazowieckie (426 mieszkań), łódzkie (420 mieszkań), dolnośląskie (409 mieszkań), śląskie (391 mieszkań), zachodniopomorskie (388 mieszkań) oraz podlaskie (385 mieszkań).

\section{Warunki mieszkaniowe w Polsce w latach 2010-2018}

Analizując podstawowe wskaźniki widoczne w tabeli 1, takie jak przeciętna powierzchnia użytkowa mieszkania ogółem oraz przypadająca na 1 osobę, przeciętna liczba osób przypadająca na 1 mieszkanie oraz 1 izbę, można stwierdzić, iż warunki mieszkaniowe w Polsce w latach 2010-2018 uległy poprawie.

Tabela 1. Przeciętne warunki mieszkaniowe w Polsce w latach 2010-2018

\begin{tabular}{|l|c|c|c|c|c|c|c|c|c|}
\cline { 2 - 9 } \multicolumn{1}{l|}{} & 2010 & 2011 & 2012 & 2013 & 2014 & 2015 & 2016 & 2017 & 2018 \\
\hline Przeciętna powierzchnia użytkowa $\mathrm{w} \mathrm{m}^{2}:$ \\
\hline 1 mieszkania & 72,3 & 72,6 & 72,8 & 73,1 & 73,4 & 73,6 & 73,8 & 74,0 & 74,2 \\
\hline na 1 osobę & 25,3 & 25,6 & 25,9 & 26,3 & 26,6 & 27 & 27,4 & 27,8 & 28,2 \\
\hline Przeciętna liczba osób na: & 2,86 & 2,84 & 2,81 & 2,78 & 2,75 & 2,72 & 2,69 & 2,66 & 2,63 \\
\hline 1 mieszkanie & 0,75 & 0,74 & 0,74 & 0,73 & 0,72 & 0,71 & 0,70 & 0,70 & 0,69 \\
\hline 1 izbę
\end{tabular}

Źródło: opracowanie własne na podstawie Rocznik Statystyczny Rzeczypospolitej Polskiej 2019, Rocznik Statystyczny Rzeczypospolitej Polskiej 2014.

Mimo widocznej poprawy wskaźników warunki mieszkaniowe w Polsce i tak znacznie odbiegają od wartości uzyskiwanych w krajach zachodniej i północnej Europy.

Przeciętna powierzchnia użytkowa mieszkania w naszym kraju zwiększyła się z 72,3 $\mathrm{m}^{2}$ w 2010 roku do 74,2 $\mathrm{m}^{2}$ w 2018 roku. Dla porównania średnia unijna w roku 2018 wyniosła 96,4 m², co plasuje nas na 20 miejscu spośród 24 badanych krajów Unii Europejskiej. Największe mieszkania w 2018 roku znajdowały się w województwie podkarpackim $\left(82 \mathrm{~m}^{2}\right)$, wielkopolskim $\left(81,5 \mathrm{~m}^{2}\right)$ i opolskim $\left(81 \mathrm{~m}^{2}\right)$, a najmniejsze w łódzkim $\left(69,4 \mathrm{~m}^{2}\right)$, warmińsko-mazurskim $\left(68,7 \mathrm{~m}^{2}\right)$ i kujawsko-pomorskim $\left(70,3 \mathrm{~m}^{2}\right)$. Na terenach wiejskich w 2018 roku wskaźnik wyniósł $94 \mathrm{~m}^{2}$, natomiast na terenach miejskich $64,7 \mathrm{~m}^{2}$. Największe różnice w wielkości mieszkań pomiędzy miastem a wsią zaobserwowano w województwie śląskim oraz małopolskim, a najmniejsze w województwie warmińsko-mazurskim. 


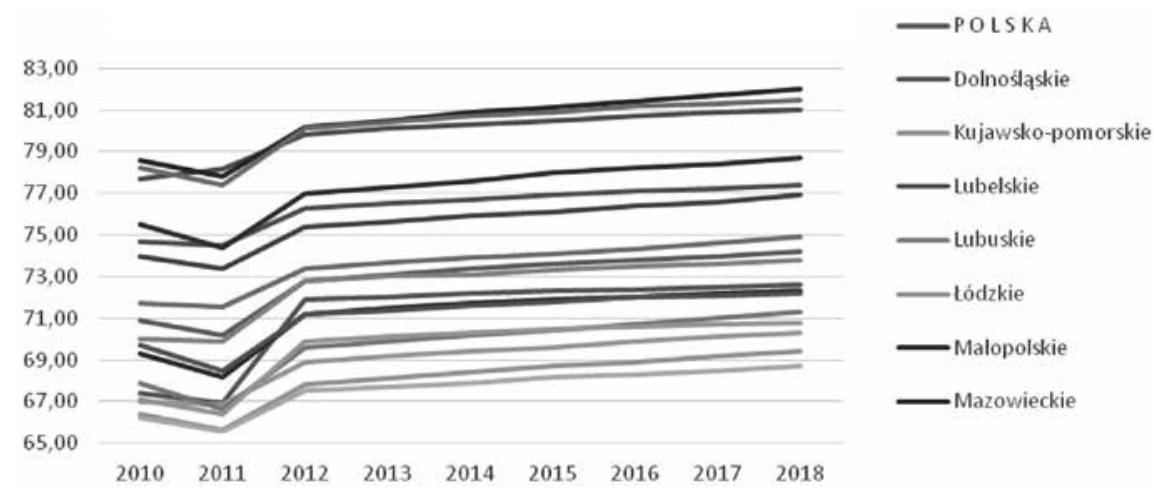

Rysunek 4. Przeciętna powierzchnia użytkowa mieszkania $w \mathrm{~m}^{2}$ w Polsce według województw w latach 2010-2018

Źródło: opracowanie własne na podstawie Rocznik Statystyczny Województw z lat 2011-2019.

Przeciętna powierzchnia użytkowa mieszkania przypadająca na jedną osobę w Polsce wzrosła z 25,3 m² w 2010 roku do 28,2 $\mathrm{m}^{2}$ w 2018 roku. Dla porównania średnia unijna w 2018 roku wyniosła 41,9 m². W 2018 roku w Polsce wskaźnik ten wyniósł $27,7 \mathrm{~m}^{2}$ na terenach miejskich i $29,1 \mathrm{~m}^{2}$ na terenach wiejskich. W miastach największą wartość odnotowano w województwie mazowieckim $\left(30,4 \mathrm{~m}^{2}\right)$ i dolnośląskim $\left(29,1 \mathrm{~m}^{2}\right)$, zaś najmniejszą w miastach w województwie warmińsko-mazurskim $\left(24,4 \mathrm{~m}^{2}\right)$ i kujawsko-pomorskim $\left(24,9 \mathrm{~m}^{2}\right)$. Na wsi największą wartość wskaźnika odnotowano w województwie podlaskim $\left(33,8 \mathrm{~m}^{2}\right)$, a najniższą w województwie podkarpackim $\left(25,7 \mathrm{~m}^{2}\right)$.
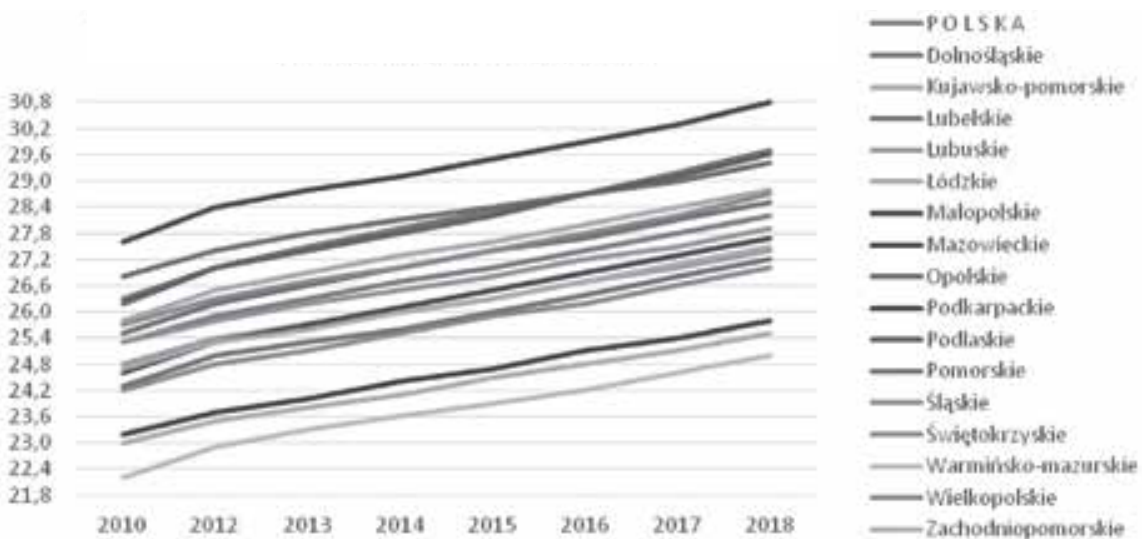

Rysunek 5. Przeciętna powierzchnia użytkowa mieszkania $w m^{2}$ przypadająca na 1 osobę w Polsce według województw w latach 2010-2018

Źródło: opracowanie własne na podstawie Rocznik Statystyczny Województw z lat 2011-2019. 
Przeciętna liczba osób przypadająca na 1 mieszkanie zmalała z 2,86 w 2010 roku do 2,63 w 2018 roku. Najwięcej osób na 1 mieszkanie w roku 2018 przypadało w województwie podkarpackim - 3,18, natomiast najmniej w województwie łódzkim - 2,41 oraz mazowieckim - 2,35. W 2018 roku mieszkania na terenach wiejskich były bardziej zaludnione niż mieszkania na terenach miejskich. Przeciętna liczba osób przypadająca na 1 mieszkanie na wsi w 2018 roku wyniosła 3,23, natomiast w mieście - 2,34. Największy wskaźnik zaludnienia na terenach wiejskich odnotowano w województwie podkarpackim - 3,61 oraz małopolskim - 3,58, a najmniejszy w województwie podlaskim - 2,79 i łódzkim - 2,98. W miastach najbardziej zaludnione były mieszkania w województwie podkarpackim - 2,71 osoby na 1 mieszkanie, a najmniej w mazowieckim i łódzkim, odpowiednio 2,10 i 2,17 osoby na 1 mieszkanie.

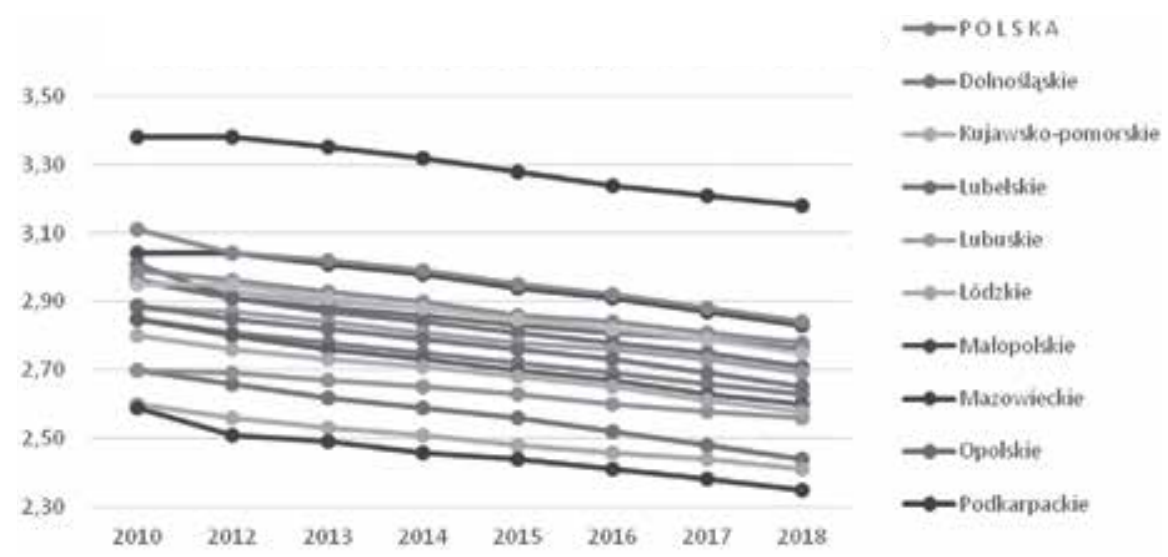

Rysunek 6. Przeciętna liczba osób przypadająca na 1 mieszkanie w Polsce według województw w latach 2010-2018

Źródło: opracowanie własne na podstawie Rocznik Statystyczny Województw z lat 2011-2019.

Przeciętna liczba izb przypadająca na 1 mieszkanie wzrosła z 3,71 w 2010 roku do 3,82 w 2018 roku. Przeciętnie najwięcej izb w roku 2018 miały mieszkania w województwie opolskim - 4,19 i podkarpackim - 4,10, zaś najmniej izb znajdowało się w mieszkaniach w województwie mazowieckim - 3,62 i łódzkim - 3,61. 


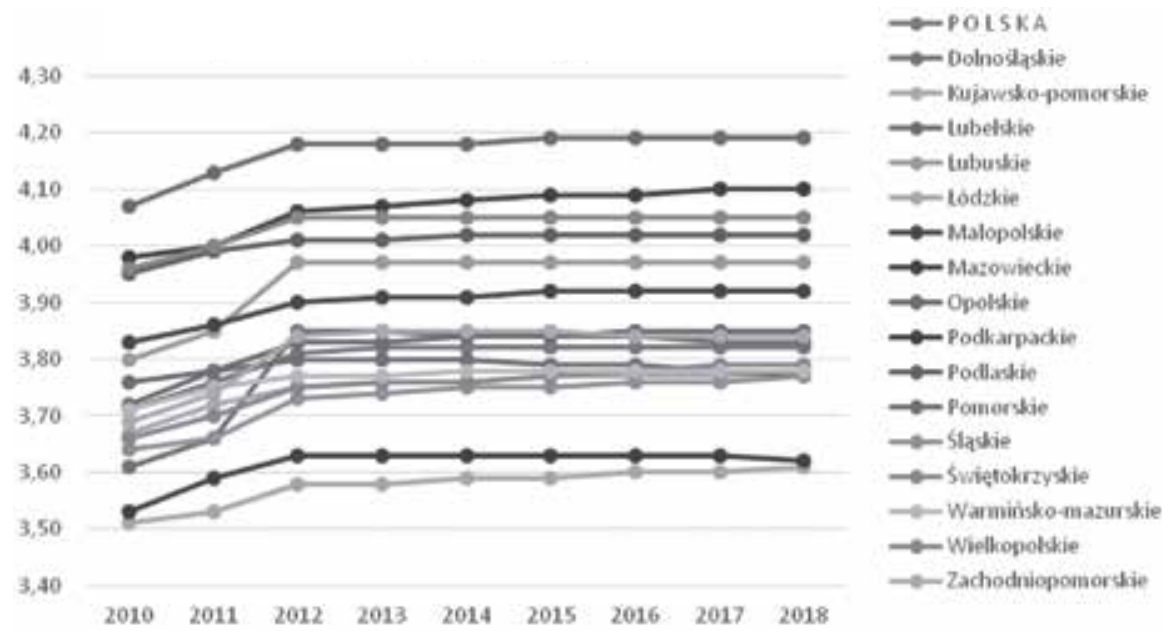

Rysunek 7. Przeciętna liczba izb przypadająca na 1 mieszkanie w Polsce według województw w latach 2010-2018

Źródło: opracowanie własne na podstawie danych Głównego Urzędu Statystycznego („Rocznik Statystyczny Województw” z lat 2011-2019).

Przeciętna liczba izb przypadająca na 1 mieszkanie miejskie w 2018 roku wyniosła 3,56, zaś na 1 mieszkanie wiejskie 4,36. Najwięcej izb w mieszkaniach wiejskich odnotowano na terenie województwa opolskiego - 4,88, a najmniej w lubelskim 3,99 . W miastach najwyższy poziom wskaźnika odnotowano w województwie podkarpackim $-3,84$ i podlaskim - 3,83, a najmniejszy w łódzkim $-3,35$ i mazowiec$\operatorname{kim}-3,39$.

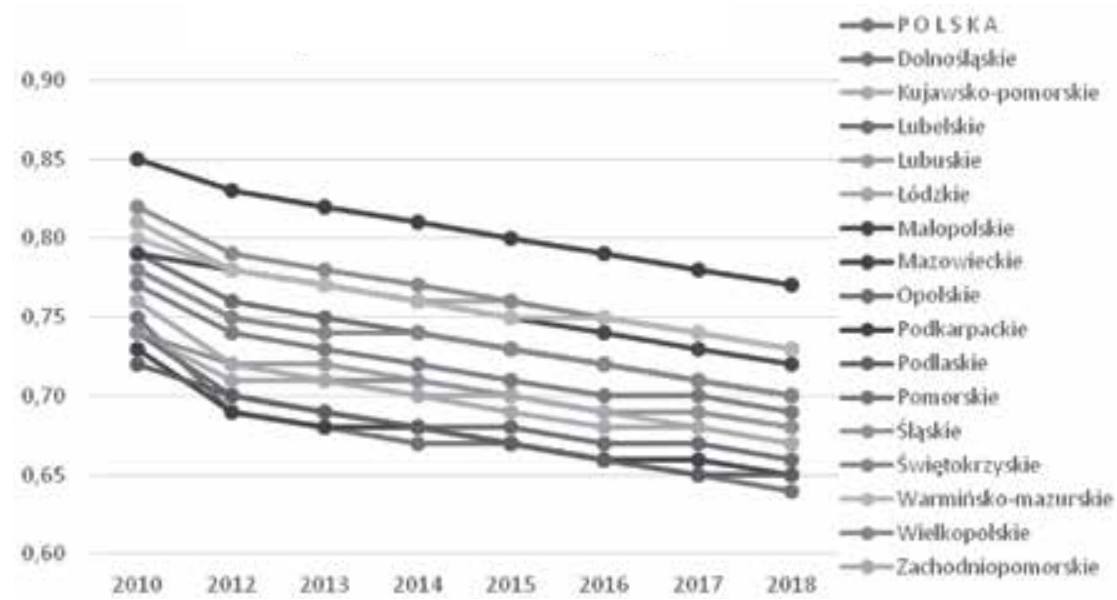

Rysunek 8. Przeciętna liczba osób przypadająca na 1 izbę w Polsce według województw w latach 2010-2018

Źródło: opracowanie własne na podstawie Rocznik Statystyczny Województw z lat 2011-2019. 
Przeciętna liczba osób przypadająca na jedną izbę spadła z 0,75 w 2010 roku do 0,69 w 2018 roku. Najniższą wartość wskaźnika w 2018 roku odnotowano w województwie dolnośląskim - 0,64 , mazowieckim i podlaskim - po 0,65 , zaś najwyższą w województwie podkarpackim - 0,77. Na terenach wiejskich w 2018 roku wskaźnik ten wyniósł 0,74 , a na terenach miejskich 0,66 . Na wsi wskaźnik wahał się od $0,83 \mathrm{w}$ województwie podkarpackim do $0,64 \mathrm{w}$ województwie podlaskim i 0,65 w województwie opolskim. W mieście wskaźnik wahał się od 0,71 w województwie podkarpackim do $0,62 \mathrm{w}$ województwie mazowieckim.

O poprawie warunków mieszkaniowych ludności świadczy również rosnący odsetek wyposażenia mieszkań w instalacje sanitarno-techniczne. W 2018 roku mieszkania wyposażone w wodociąg stanowiły $96,9 \%$, w ustęp $93,8 \%$, a w łazienkę 91,5\%. Obszarem wymagającym doinwestowania jest dostęp mieszkań do centralnego ogrzewania oraz gazu sieciowego. Obecnie dostęp do centralnego ogrzewania posiada $82,6 \%$ mieszkań, a do gazu sieciowego $55,5 \%$.

miasto

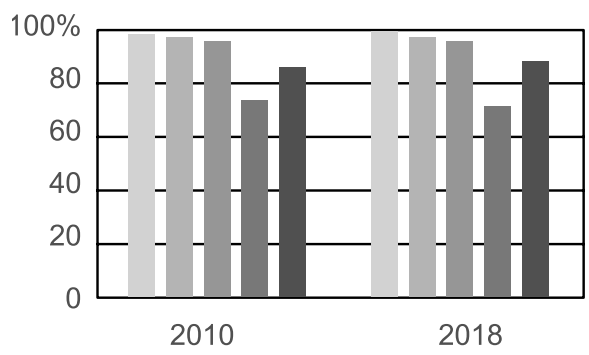

wieś

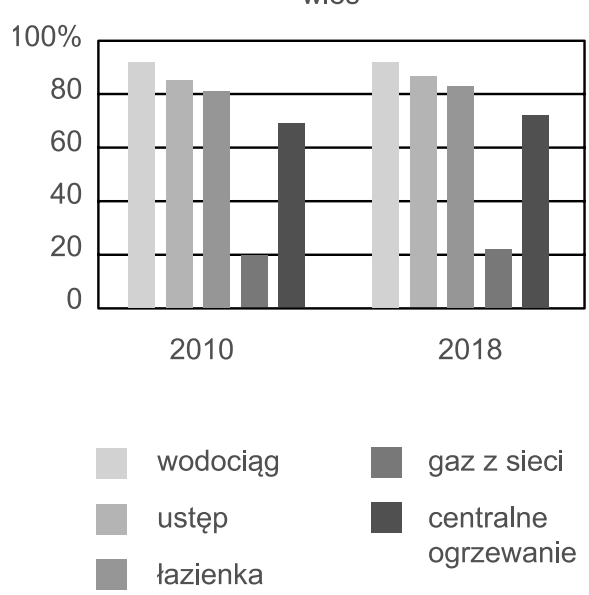

Rysunek 9. Mieszkania wyposażone w instalacje w Polsce w latach 2010 oraz 2018 (w \%)

Źródło: opracowanie własne na podstawie Rocznik Statystyczny Rzeczypospolitej Polskiej 2019. 
Powyższy wykres przedstawia dysproporcje w wyposażeniu mieszkań w instalacje sanitarno-techniczne pomiędzy terenami miejskimi i wiejskimi. Obszary wiejskie potrzebują doinwestowania szczególnie w zakresie dostępu do gazu z sieci. Odsetek mieszkań z dostępem do gazu sieciowego na wsi wynosi $22,5 \%$, podczas gdy w mieście jest to $71,4 \%$.

\section{Obrót nieruchomościami mieszkaniowymi}

Według danych Głównego Urzędu Statystycznego średnia cena powierzchni użytkowej mieszkania w 2018 roku wyniosła 4926 zł $/ \mathrm{m}^{2}$. W ostatnich latach zaobserwowano wzrost cen mieszkań we wszystkich lokalizacjach.

\begin{tabular}{|c|c|c|c|c|c|c|c|c|}
\hline & & & & & 4697 & 4777 & 4849 & 5090 \\
\hline 3652 & 3999 & 4050 & 3972 & 4236 & & & & \\
\hline & & & & & & & & \\
\hline a & - & 2857 & 2872 & 2832 & 3088 & 3134 & 3148 & 3433 \\
\hline 2514 & 2433 & & & & & & & \\
\hline 2010 & 2011 & 2012 & 2013 & 2014 & 2015 & 2016 & 2017 & 2018 \\
\hline
\end{tabular}

Rysunek 10. Średnie ceny lokali mieszkalnych według lokalizacji w Polsce w latach 2010-2018 (zt/m²)

Źródło: opracowanie własne na podstawie Obrót nieruchomościami z lat 2010-2018.

W 2018 roku na rynku wtórnym najwyższe średnie ceny sprzedaży mieszkań odnotowano w województwie mazowieckim $\left(7503 \mathrm{zł} / \mathrm{m}^{2}\right)$, a następnie w województwie małopolskim $\left(5393 \mathrm{zł} / \mathrm{m}^{2}\right)$ i pomorskim $\left(5323 \mathrm{zl} / \mathrm{m}^{2}\right)$, zaś najniższe w województwie opolskim i lubuskim $\left(2790 \mathrm{zł} / \mathrm{m}^{2}\right)$. Na rynku pierwotnym najwyższe średnie ceny sprzedaży odnotowano w województwie mazowieckim (6862 zł/m²) i małopolskim $\left(6400 \mathrm{zz} / \mathrm{m}^{2}\right)$, a najniższe w województwie lubuskim $\left(3812 \mathrm{zz} / \mathrm{m}^{2}\right)$ i śląskim $\left(4207 \mathrm{z} / / \mathrm{m}^{2}\right)$. 


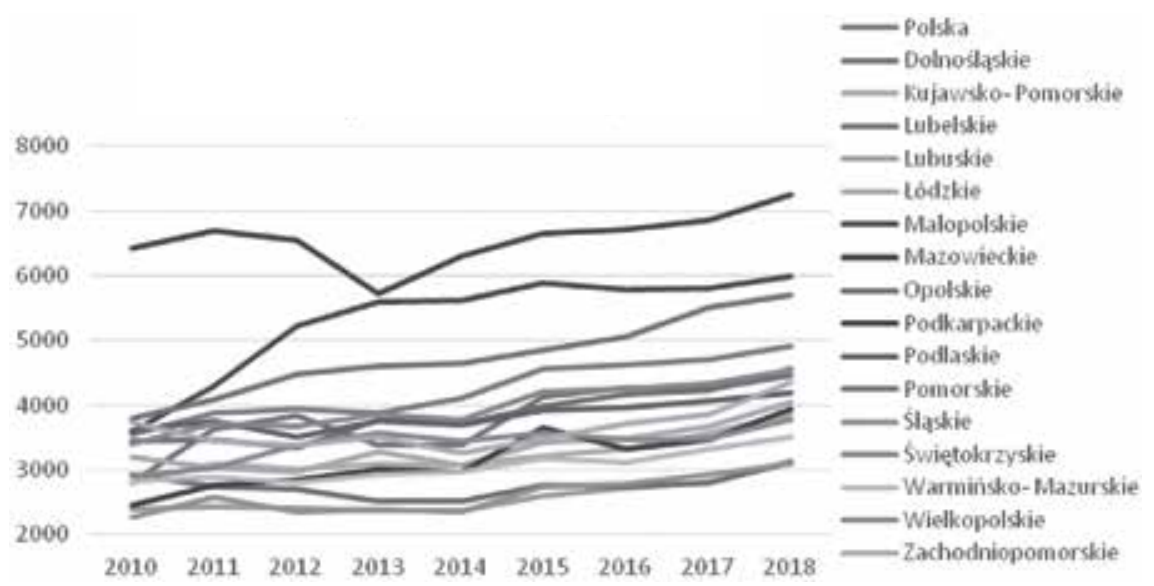

Rysunek 11. Średnie ceny lokali mieszkalnych według województw w Polsce w latach 2010-2018 (zt/m²)

Źródło: opracowanie własne na podstawie Obrót nieruchomościami z lat 2010-2018.

W 2018 roku na rynku pierwotnym, zarówno w mieście, jak i na wsi, najczęściej sprzedawane były mieszkania, których cena wahała się w przedziale od $4001 \mathrm{zł} / \mathrm{m}^{2}$ do $6000 \mathrm{zł} / \mathrm{m}^{2}$. Na rynku wtórnym w miastach najczęściej sprzedawano mieszkania, których cena wynosiła od $2001 \mathrm{do} 4000 \mathrm{zl} / \mathrm{m}^{2}$, natomiast na wsi były to mieszkania o cenie niższej niż $2000 \mathrm{zł} / \mathrm{m}^{2}$.

O dostępności mieszkań decyduje nie tylko poziom cen, ale także możliwości finansowe nabywców. Obecnie w Polsce sytuacja dochodowa gospodarstw domowych uległa znaczącej poprawie, co przekłada się na zainteresowanie zakupem mieszkania. Rosnący popyt na mieszkania związany jest ze wzrostem wynagrodzeń, mniejszym bezrobociem oraz stabilnymi i niskimi stopami procentowymi.

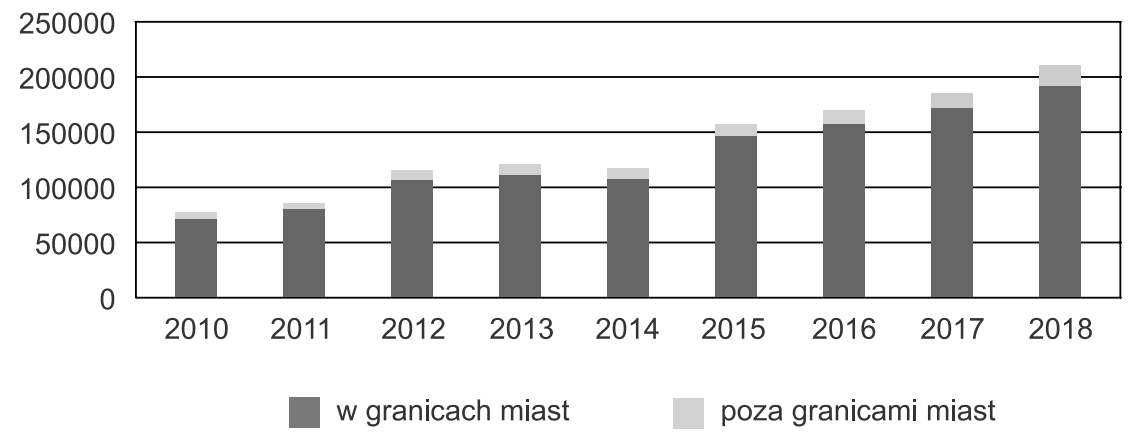

Rysunek 12. Liczba transakcji kupna/sprzedaży lokali mieszkalnych w Polsce w latach 2010-2018

Źródło: opracowanie własne na podstawie Obrót nieruchomościami z lat 2010-2018. 
W zależności od celu zakupu nieruchomości wśród popytu mieszkaniowego rozróżniamy popyt konsumpcyjny oraz inwestycyjny. Popyt inwestycyjny na mieszkania związany jest z możliwością osiągnięcia stosunkowo wysokich stóp zwrotu z wynajmu mieszkania. Niskie oprocentowanie depozytów bankowych skłania gospodarstwa domowe do inwestowania środków w nieruchomości zamiast lokowania środków w depozyty bankowe lub obligacje skarbowe. Popyt konsumpcyjny natomiast jest wynikiem dążenia gospodarstw domowych do zaspokojenia warunków bytowych, do jakich należy zakup własnego mieszkania.

\section{Kredyty mieszkaniowe}

Sektor finansowy ma kluczowe znaczenie dla rynku nieruchomości, bowiem oferuje finansowanie zakupu nieruchomości. Według danych Komisji Nadzoru Finansowego na koniec 2018 roku łączna liczba kredytów mieszkaniowych udzielonych gospodarstwom domowym wyniosła 2,2 mln. Łączna wartość kredytów mieszkaniowych wyniosła $406423 \mathrm{mln}$ zł, a średnia wartość kredytu mieszkaniowego wyniosła 185,4 tys. zł. Kredyty na zakup mieszkania stanowiły $60 \%$ ogółu kredytów mieszkaniowych. Z kolei wśród kredytów zaciągniętych na zakup mieszkania dominowały kredyty na zakup nieruchomości mieszkaniowych na warszawskim rynku.

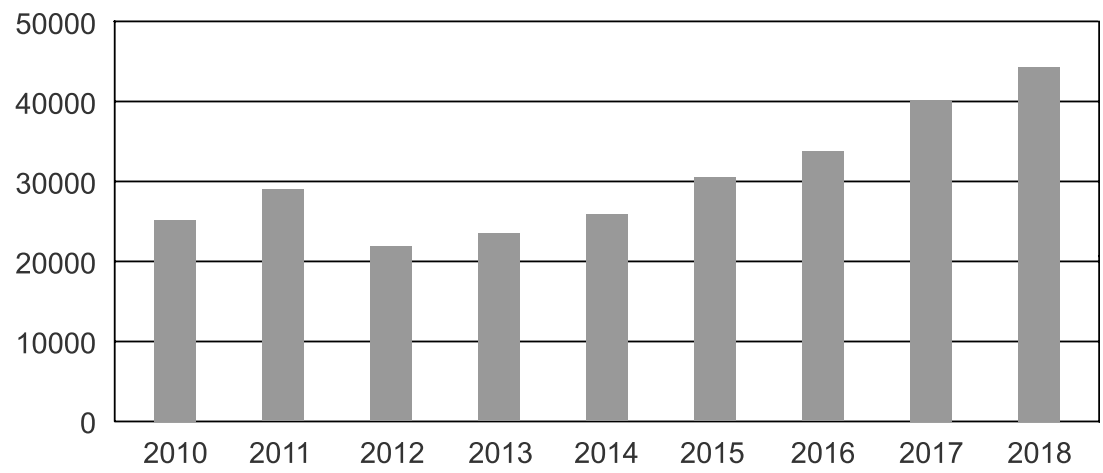

Rysunek 12. Wartość kredytów mieszkaniowych w Polsce w latach 2010-2018 (w mln zł)

Źródło: opracowanie własne na podstawie Wyniki badania portfela kredytów mieszkaniowych i konsumpcyjnych gospodarstw domowych według stanu na koniec 2018 r., 2019.

Analizując sytuację na rynku kredytów mieszkaniowych, należy zwrócić uwagę, iż w latach 2013-2018 nastąpił duży wzrost średniej wartości kredytu (aż o 48,9\%), który głównie wynikał ze wzrostu cen nieruchomości. Silne wzrosty cen nieruchomości mogą doprowadzić do nadmiernego zadłużenia gospodarstw domowych lub do wykluczenia z rynku nieruchomości gospodarstw domowych o niskich dochodach. 


\section{Podsumowanie}

Na sytuację mieszkaniową Polaków przez wiele lat wpływały różne uwarunkowania historyczne. Na przestrzeni ostatnich lat stan polskiego mieszkalnictwa uległ poprawie, lecz mimo to nadal zajmuje jedno z ostatnich miejsc w krajach Unii Europejskiej.

Analizując podstawowe wskaźniki, takie jak przeciętna powierzchnia użytkowa mieszkania, przeciętna powierzchnia mieszkania przypadająca na 1 osobę, przeciętna liczba osób przypadająca na 1 mieszkanie oraz 1 izbę, można stwierdzić, iż warunki mieszkaniowe w Polsce w latach 2010-2018 uległy poprawie.

Z uwagi na niskie stopy procentowe coraz częściej mieszkania nabywane są w celach inwestycyjnych.

Rosnący popyt na mieszkania wpływa na wzrost cen nieruchomości mieszkaniowych oraz wolumen udzielanych kredytów mieszkaniowych.

Rynek lokali mieszkalnych w Polsce pozostaje w silnej korelacji z rynkiem kredytów hipotecznych.

\section{Bibliografia}

Kucharska-Stasiak E. (2016), Ekonomiczny wymiar nieruchomości, Wydawnictwo Naukowe PWN S.A., Warszawa.

Obrót nieruchomościami, z lat 2010-2018, Informacje i opracowania statystyczne, Główny Urząd Statystyczny, Warszawa.

Raport o sytuacji na rynku nieruchomości mieszkaniowych i komercyjnych $w$ Polsce w 2018 r. (2019), Narodowy Bank Polski, Departament Analiz Ekonomicznych, Warszawa.

Rocznik Statystyczny Rzeczypospolitej Polskiej 2014, Główny Urząd Statystyczny, Zakład Wydawnictw Statystycznych, Warszawa.

Rocznik Statystyczny Rzeczypospolitej Polskiej 2019, Główny Urząd Statystyczny, Zakład Wydawnictw Statystycznych, Warszawa.

Rocznik Statystyczny Województw, z lat 2011-2019, Główny Urząd Statystyczny, Zakład Wydawnictw Statystycznych, Warszawa.

Wyniki badania portfela kredytów mieszkaniowych i konsumpcyjnych gospodarstw domowych wedtug stanu na koniec 2018 r. (2019), Komisja Nadzoru Finansowego, Warszawa. 


\section{Summary}

Housing in Poland in the years 2010-2018

This article discusses housing in Poland in the years 20102018. It presents housing conditions in Poland. To this end, the 2010-2018 GUS data on the housing market are analysed. The structure of the article is as follows: after a brief introduction, the first part of the text, in a synthetic way, presents the size of housing resources in Poland. The second part of the article analyses the basic housing conditions of residential property on the regional markets in Poland (average usable floor space of the flat, average flat area per 1 person, average number of rooms in a flat, average number of people per 1 flat and 1 room, average number of rooms in the apartment). Part three discusses the turnover on the residential market. The fourth part presents the role of mortgages in financing the purchase of real estate. A synthetic statement summarises the text.

Keywords: property, real estate, property market, real estate market, residential premises, primary market, real estate prices, secondary market, supply on the real estate market, demand on the real estate market, housing conditions 